INTERNATIONAL JOURNAL OF MULTIDISCIPLINARY RESEARCH AND ANALYSis

ISSN(print): 2643-9840, ISSN(online): 2643-9875

Volume 04 Issue 08 August 2021

DOI: 10.47191/ijmra/v4-i8-13, Impact Factor: 6.072

Page No.- $1145-1158$

\title{
Production of a Model Water Fountain Using Ceramics for Interior Decoration in Anambra State
}

\author{
Okonkwo, Ivan Emeka Phd ${ }^{1}$, Emelogu, Chinenye ${ }^{2}$, Anonye Obianuju Maria ${ }^{3}$ \\ ${ }^{1}$ Department of Fine and Applied Arts, Faculty of Environmental Sciences, Nnamdi Azikiwe University, Awka \\ ${ }^{2}$ Department of Fine and Applied Arts, Federal University, Ndufu Alike Ikwo \\ ${ }^{3}$ Department of Fine and Applied Arts, Federal Polytechnic Oko
}

ABSTRACT: Water fountains have been produced by sculptors, architects and engineers over the years in Nigeria, however the production of water fountains in ceramics is not popular and could be rarely seen in public spaces, longues and interiors of public buildings especially in Anambra State. In view of this; this project entitled "Production of a Water Fountain using Ceramics for Interior Decoration in Anambra State" was designed to enlighten the society that ceramic materials could be used for the production of water fountain instead of other media like cement and metal. Also, that water fountain when situated in the interior of the house will help in relaxation thereby reducing some tensions and stress after all day work. Data used were sourced from both primary and secondary sources. An explorative method of research was employed in the project. The processes involved in the execution of the work were showcased in detail. The study observes that majority of water fountains seen around were made using cement instead of ceramics, which is more durable, hygienic, attractive and nature friendly, hence the need for this project. This work encourages more research in this area of study.

\section{INTRODUCTION}

Decoration plays a very important role in enhancing a conducive atmosphere especially in the homes, and offices. This brought about the idea of producing water fountain for interior decoration. Fountain comes from the latin word fons or fontis (a source of spring) it is a piece of architecture which pours water into a basin or jets it into the air to supply drinking water or for a decorative or dramatic effect. (Wikipeadia, 2007).

Water fountain according to Cambridge Advanced Learner's Dictionary and Thesaurus (2017) "is a device usually in a public place that supplies water for drinking". Merriam Webster (2017) states, "water fountain as a device or structure that sends a stream of water into the air in a garden and park".

Fountains were originally purely functional, connected to springs or aqueducts and used to provide drinking water and water for bathing and washing to the cities, towns and villages. Until the late $19^{\text {th }}$ century most fountains operated by gravity and need a source of water higher than the fountain such as a reservoir or aqueduct to make the water flow or jet into the air. In addition to providing drinking water, fountains were used for decoration and to celebrate their builders. (Wikipedia, 2017).

History has it that Roman fountains were decorated with bronze or stone masks of animals or heroes. In the middle Ages, Moorish and Muslim garden designers used fountains to create miniature versions of the gardens of paradise. King Louis XIV of France used fountain in the Gardens of Versailles to illustrate his power over nature.

Water fountains date back thousands of years. Ancient Greeks built water fountains around springs that were thought to have magical powers. Water fountains included replicas of the Greek gods and goddesses. Ancient Romans copied this Greek design in the construction of Ancient Roman fountains. Some of these complicated fountains were built during the Renaissance $(1500-1700)$ and the most world famous fountains were constructed from $1600-1700$. Many of the fountains constructed in the US during $1800-1900$ copied the classical designs of different eras. The newer fountains constructed since the late 1900s have more complex designs with artificial effect which include electronic mechanisms to control the flow of water, lighting and sounds.

Today, fountain is designed for recreation such as splash fountains where residents can cool off in the summer, for drinking, and also as ornamental decoration in city parks, squares and gardens. Sheets of water flow over varied surfaces of 


\section{Production of a Model Water Fountain Using Ceramics for Interior Decoration in Anambra State}

stone, concrete or metal. Basins may overflow from one into another; the overflow may imitate a natural cascade. Many fountains are located in small, artificial, ornamental ponds, basins and formal garden pools, and they often include sculpture.

\section{STATEMENT OF THE PROBLEM}

There are many fountains for both interior and exterior decorations. However, most of the existing fountains in Ekwulobia are made of cement or metal and designed by architects, sculptors and non-ceramists. In view of this problem, the researcher attempts at exposing the fact that ceramic materials could be used for the production of fountains instead of other media, such as cement and metal. It is obvious that ceramics are hygienically better than other materials. They are also more durable and with a higher aesthetic appeal than most other media. Hence, the researchers try to propagate the use of ceramics for production of fountains through this project.

\section{AIM OF THE STUDY}

The aim of this project is to produce a model water fountain using ceramics for interior decoration.

\section{OBJECTIVES OF THE STUDY}

The objectives of this research are as follows;

- $\quad$ To create a model water fountain that will arrest the character of the environment.

To create an atmosphere that will enhance a stress free environment.

To relate ceramics with science and engineering.

To add beauty to the surrounding.

To document the production processes in a written project formats and exhibit the finished practical project for public view.

\section{Scope of the Study}

This study is focused on the production of a model water fountain using ceramics materials and techniques of production in Anambra State.

\section{Limitation of the Study}

The major problems encountered on the course of this research are sourcing of materials to be used in executing the practical project. Also, most written documents found by the researchers were mainly on fountains built with cement instead of clay.

\section{Significance of the Study}

This study provides more insight into the art of producing fountain.

It also provides more information on the raw materials used in producing fountains in ceramics.

It serves as a reference material for researchers in Fine and Applied Arts, Engineering, Architecture and other related disciplines.

The practical project (fountain) can provide environmental, mental and physical health benefits for everyone in the environment. The waterfall proves a very effective and attractive way to help people to relax. The flow of water will rescue one from stress thereby making his/her to live longer.

\section{Research Questions}

How can a model water fountain that will arrest the character of the environment be created?

Can this project work create an atmosphere that will enhance a stress free environment?

How does this ceramic work relate with science and engineering?

Can this work beautify the surrounding?

Can this project be documented for written project format?

\section{REVIEW OF RELATED LITERATURE}

The researchers in this study reviewed some related literature as well as related works done previously by some professionals.

\section{Conceptual Framework}

Fountain

Fountain, according to Oxford Dictionary (2017), is an ornamental structure in a pool or lake from which one or more jets of water are pumped into the air. Online English Dictionary (2009) defines fountain as a structure through which a stream of 


\section{Production of a Model Water Fountain Using Ceramics for Interior Decoration in Anambra State}

water is pumped into the air and falls down again, while American Heritage Dictionary of the English (2016) sees it as a structure often decorative from which a jet or stream of water issues. According to Kerneman Webster's College Dictionary (2010), fountain is a jet or stream of water caused by mechanical means to spout from an opening or structure.

Furthermore, it is a reservoir for a liquid to be supplied continuously as in a fountain pen. In addition, fountain is a decorative ware designed to pump water into the air for the purpose of entertainment and beautifying the environment. On hot days and after working all day, the one thing that people look for is a water fountain. Water fountains have the ability to satisfy, amuse, and decorate. A fountain comes from the latin language and simply means a source of spring. Water fountains are tanks that dispense water into sink or a stream for people to drink or for people to enjoy. Fountains have been around for a long time and were found to associate with springs and aqueducts. Usually, they were used to gather water for people in the past to drink, cook and even bath in.

Fountains were powered by gravity and needed to essentially run down hill or people to use them. Within the past 100 years fountains have to be powered by electricity or battery. With the discovery of electric power, fountain design and function have taken on a new meaning. Fountains can now be found everywhere from city parks to school gyms.

Outdoor water fountains have become an icon for many communities. Massive water fountains are found at the heart of many city parks and people of all ages have sat on the side of the fountain on a hot day and cooled their feet. This has also taken on decorative designs that many times a statue of a person or an animal object is found at the center of the fountain. With the invention of the water pump, water can now be pumped through the fountain to produce a stream of water or develop a waterfall effect for people to enjoy.

However, water fountains have also found their way indoors. Some schools place them around the gym floor for thirsty kids to use after a hard day of play. Major corporations have taken the liberty to place drinking fountains and water coolers around for employees to use while working. Sometimes in the front of a major building a potential visitor will enter the door and find a massive indoor water fountain that has become a status symbol for businesses today.

Paun (2017) states that water fountains have created joy in public spaces for centuries. It is entirely possible to have the beauty of moving water in the home garden as well. In a traditional fountain, water issues from a source, fills a basin, and drains away. The water may be no more than a trickle. He also says that fountains can be embedded in a wall, or they could be free standing. The water might flow over varied surfaces and basins could be arranged so that the water over flows from one into another. The fountain might include sculpture and an ornamental pool at times. If there is enough pressure, fountains often include a jet, which forces the water into the air.

\section{Theoretical Frame Work}

The study is driven by the Aesthetic Theory and the Theory of Water Cycle. Aesthetics is a branch of philosophy that deals with beauty, how beauty is seen and how it is evaluated. Thus, aesthetics is defined by several different authors as a critical reflection on art, culture and nature. Aesthetic theory therefore means "the philosophical theory or set of principles governing the ideas of beauty at a given time and place". The clean lines, bare surface and sense of space that bespeak the machine - age aesthetic, the cubist aesthetic"

Aesthetic theory, according to the German Philosopher, Theodore Adorno (1970), is retraceable to the historical evolution of art into the paradoxical state of "semi-autonomy" within capitalist modernity, considering the social - political implications of this progression. Some critics have described the work as Adorno's Magnum opus and ranked it among the most important pieces of aesthetics published in the $20^{\text {th }}$ century.

Adorno is concerned not only with such standard aesthetic preoccupations as function of beauty and sublimity in art, but with the relations between art and society. He feels that modern art's freedom from such restrictions as cult and imperial functions that had plagued previous eras of art has led to arts expanded critical capacity and increased formal autonomy. With this expanded autonomy comes arts increased responsibility for societal commentary.

However, Adorno does not feel that overtly politicized content is art's greatest critical strength: rather he champions a more abstracted type of truth-content: (Wahrheitsgehalt) unlike Kantian or Idealist aesthetics, Adorno's aesthetics locates truths-content in the art object, rather than in the perception of the subject. Such content is however, affected by art's self consciousness at the hands of its necessary distance from society, which is perceptible in such instances as the dissonances inherent in modern art. Trust - content is ultimately found in the relation between multiple dialectional interactions that emerge from the art works position(s) relative to subject and greater societal dialectics within the work itself.

However, aesthetics may be defined narrowly as the theory of beauty, or more broadly as that together with the philosophy of art. The traditional interest in beauty itself broadened, in eighteen century, to include the sublime and since 1950 or so the member of pure aesthetic concepts discussed in the literature has expanded even more. 


\section{Production of a Model Water Fountain Using Ceramics for Interior Decoration in Anambra State}

Traditionally, the philosophy of art concentrated on its definition, but recently this has not been the focus with careful analysis of aspects of art largely replacing it. Philosophical aesthetic is here considered to center on these latter- day developments. Thus, after a survey of ideas about beauty and related concepts, questions about the value of aesthetics experience and the variety of aesthetic attitudes will be addressed before turning to matters which separate art from pure aesthetics, notably the presence of intention. That will lead to a survey of some of the main definitions of art which have been proposed, together with an account of the recent "de-definition" period. The concepts of expression, representation, and the nature of art objects will then be covered.

Aesthetic did not begin to emerge until the widening of leisure activities in the eighteenth century. By far the most thorough going and influential of the early theorists was Immanuel Kant, towards the end of the eighteenth century. Kant is sometimes thought of as a formalist in art theory: that is to say, someone who thinks the content of a work of art is not of aesthetic interest. But this is only part of the story. Certainly he was a formalist about the pure enjoyment of nature, but for Kant, most of the arts were impure, because they involved a "concept" in all, Kant's theory of pure beauty had for aspects. Its freedom from concepts, its objectivity, disinterests the spectator, and its obligatoriness.

Adorno's claims about art in general stem from his reconstruction of the modern art movement. So a summary of his philosophy of art sometimes needs to signal this by putting "modern" in parenthesis. The book begins and ends with reflections on the social character of modern art. Two themes stand out in these reflections. One is an updated Hegelian question whether art can survive in a late capitalist world.

The other is an updated Marxian question whether art can contribute to the transformation of this world. Whether addressing both questions, Adorno retains from Kant the notion that art, proper "fine art", is characterized by autonomy. But Adorno combines this Kantian emphasis on form with Hegel's emphasis on intellectual import (Geistiger Gehalt) and Marx's emphasis on art's embeddedness in society as a whole. The result is a complex account of the simultaneous necessity and illusoriness of the art work's necessary and illusory autonomy, in turn is the key to (modern) art's social character namely, to be "the social antithesis of society". Adorno regards authentic works of modern art as social monads.

Zuidervaat (1991) uses concept of truth in art, and lays out the approaches Adorno takes to unpack the experience of truth in Art, the role of philosophy in uncovering this truth, and the resistance of art to incorporation into a philosophical body of truth.

In the process we get insight into key concepts for Adorno's approach to art, including its dialects of production, its social and historical situatedness, its critical and negative content and its relationship to philosophy. The book ends with assessing the limits of Adorno's aesthetics over against later version steeped in critical theory of modernism, while showing the limits of these interpretive approaches relative to Adorno's concept of truth. Adopting aesthetic theory is consequential for the knowledge of the decorative and dramatic effects of fountain. All fountains, even those designed for a specific use, are generally pleasing.

Finally, all water fountain are beautiful and also remain the center of attraction wherever it is situated.

\section{Theory of Water Cycle}

It is also called hydrologic cycle, and this involves the continuous circulation of water in the earth to atmosphere of the system of many processes involved in the water cycle, the most important are evaporation, transpiration, condensation, precipitation, and runoff. Although the total amount of water within the cycle remains essentially constant, its distribution among the various processes is continually changing. (www.britannica.com).

According to Fellman (2005) water from the ocean is evaporated due to sunshine as a result that water is held as vapour until the air becomes supersaturated then the atmospheric moisture is returned to the earth. Surface as solid or liquid precipitation to complete the cycle.

The American Heritage Dictionary of English Language (2016) defines water cycle as the continuous process by which water is circulated throughout the earth and the atmosphere through evaporation, condensation, precipitation and the transpiration of plants and animals.

However, water cycle means the circulation of the earth's water in which water evaporates from the sea into the atmosphere, where it condenses and falls as rain or snow, returning to the sea by rivers or returning to atmosphere by evaporatranspiration (Collins English Dictionary - complete and unabridged 2014).

Wright and Boorse (2012) opined that the basic cycle consists of water rising to the atmosphere through evaporation and transpiration and returning to the land and oceans through condensation and precipitation.

Also, the American Heritage Students Science Dictionary (2014) pointed water cycle as the continuous process by which water is distributed through out the Earth and its atmosphere. Energy from the sun causes water to evaporate from oceans and 


\section{Production of a Model Water Fountain Using Ceramics for Interior Decoration in Anambra State}

other bodies of water and from soil surfaces. Plants and animals also add water vapour to the aid by transpiration. As it rises into the atmosphere, the water vapour condenses to form clouds. Rain and other forms of precipitation return water to the Earth, where it flows into bodies of water and into the ground, beginning the cycle over again.

Boehm, Armstrong and Hunkins (2003) stated that the total amount of water on the earth does not stay in one place either. Instead the water moves constantly. Also that the water goes from the oceans to the air, to the ground and finally back to the oceans.

Evaporation, one of the major processes in the cycle is the transfer of water from the surface of the Earth to the atmosphere. By evaporation, water in the liquid states is transferred to the gaseous, or vapour state. The transfer occurs when some molecules in a water mass have attained sufficient kinetic energy to eject themselves from the water surface. The main factors affecting evaporation are temperature, humidity, wind speed, and solar radiation. The direct measurement of evaporation, though desirable is difficult and possible only at point locations. The principal source of water vapour is the oceans, but evaporation also occurs in soils, snow and ice. Evaporation from snow and ice, the conversion from solid to vapour is known as sublimation.

Transpiration is the evaporation of water through minute pores or stomata, in the leaves of plants. For practical purposes, transpiration and the evaporation from all water, soils, snows, ice, vegetation, and other surfaces are lumped together and called evaporatra aspiration.

Water cycles begin and end in the ocean.

Condensation is the transition process from the vapour state to the liquid state. This takes place as soon as the air contains more water vapour than it can receive from a free water surface through evaporation at the prevailing temperature. By condensation, water vapour in the atmosphere is released to form precipitation.

Precipitation that falls to the Earth is disturbed in four ways: Some returned to the atmosphere by evaporation, some may be intercepted by vegetation and then evaporated from the surface of leaves, some percolate into the soil by infiltration, and the remainder flows directly as surface runoff into the sea. Some of the infiltrated precipitation may later percolate into streams as groundwater runoff.

The diagram below simplifies how water is being circulated.

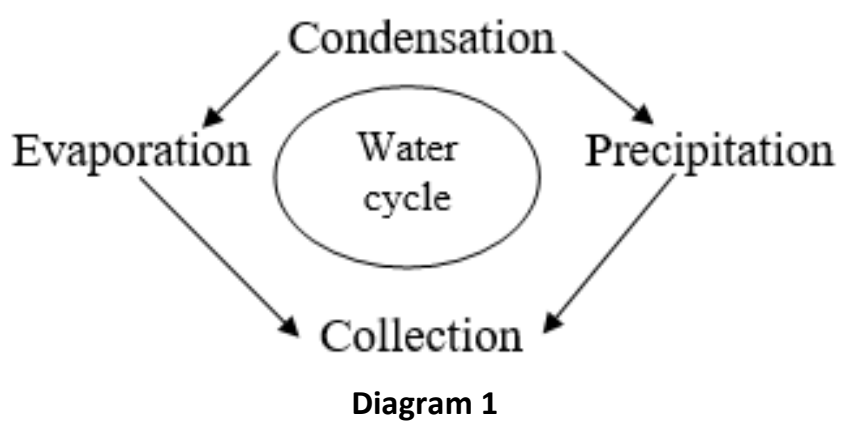

Water is very important for all living beings. Water cycle keeps providing us with fresh water continuously. This is a reversible cycle, which means every stage in the cycle keeps repeating itself. This is also applicable in the water fountain.

\section{Empirical Studies}

Fountains were originally purely functional, connected to springs and used to provide drinking water and water for bathing and washing to the residents of cities, towns and villages. But in ancient Rome they were used as decorative elements in the gardens and courtyards. The art of fountains reached its peak in the fountains of the palaces of Moorish Spain in the $14^{\text {th }}$ century, in the Italian Renaissance garden in the $15^{\text {th }}$ and $16^{\text {th }}$ century; in the Versailles in the seventeenth century; and the decorative fountains of Rome in the seventeenth and eighteenth century.

Atlee (2006) stated that the tradition and style of gardens is thought to have originated at about 400BC Persia (Iran). Decorated pottery from that period in Persia history displays typical cross plans of the Persia garden. Travelers to the region recorded the earliest descriptions of garden during the $14^{\text {th }}$ century and travelers recorded actual illustration of the design of the gardens as early as the $17^{\text {th }}$ century. Gardens were designed to provide relaxation and they were typically enclosed. The structural aspect of Persia garden design were most concerned with the effects of sunlight. Texture and shapes were chosen for their ability to direct sunlight. Trees and structure were carefully situated to allow sunlight to come in and also to provide and offer utility for the garden. 


\section{Production of a Model Water Fountain Using Ceramics for Interior Decoration in Anambra State}

The Persian Empire was centrally located in the mountains where water was considered a valued commodity. When water was used in gardens, it was to provide a method of irrigation. The Persia included a Quanta to irrigate the garden and the environment. Quanta are tunnels beneath the water table that are connected by structure to draw water to the surface. Trees were planted on ditches to prevent water from evaporating. The presence of water in Persia gardens dates back to the period between 201BC and 700BC. In later years, designs became more elaborate to include fountains and ponds. As time goes on, aesthetic aspects of the garden became mere popular and more important than the utility of gardens. As a result of this, gardens were able to channel water to create design.

During the $13^{\text {th }}$ century, Mongolian empire invaded Persia thereby making them to emphasize more on the aspect of the garden. Greenery was used to create new dimension. The Mongolian continued the tradition of Persia Garden in their other empires, particularly India. During the $17^{\text {th }}$ to $18^{\text {th }}$ century, the design of garden extended to palaces. Later, European influences, such as those by France, Russia, and the UK, lead to variation to the use of water and flowers. The Arab empire of northern India developed the Persian style of garden in the construction of Mughal style of gardens. Unlike in Persia, this garden were constructed where water was plentiful and included large amount of standing water as well as more elaborate pools, screams, water falls and pavilions. The used of light and water was so sophisticated that a form of water all was created.

The Chadar is a form of water fall that maximizes the effect of sunlight on the water such as with reflecting pools. In the western area of Arab empire, the Persia style was adapted in the construction of Moorish gardens. This garden made use of gravity to create a water supply. Arabs maintained respect for scarce water sources in constructing fountains, particularly jet fountain. Severe restraint was placed on the consumption of water for jet fountains. Unlike with Greek and Roman gardens, the likeness of men was forbidden in the construction of Islamic gardens. Also, with the exception of certain Mushal gardens, this garden used lesser quantities of water. Irrigation methods were combined with channels, bowls and fountains. Lotus pattern were used when lesser quantities of water seemed greater and over flows form basins were designed to send water to secondary channels. The lack of gravity feed water provided for designs such as the Moorish design, were water used in displays was channeled to irritation systems once its display function was fulfilled.

The western culture of gardens stems from the designs of Greece and Ancient Roman gardens and incorporates method of piping and gravity. The development of the water powered pump in Rome lead to the gravity fed fountains and this water fountain design spread to greater Europe. The renaissance of Italy provided for the development of cascading or downward falling fountains. France developed the more elaborate water fountains (Allain and Christiany 1994).

The Japanese and Chinese replicated the downward flowing water design except they used sand and rocks rater than fountains. The renaissance of the orient presented a more natural approach to a gardens. Rising jet fountains were rarely used and when fountains were included in gardens, they included naturally occurring water flows through dams to lakes and informal pools.

Technologically, fountains from Roman times till now operated largely by gravity, requiring a source of water higher than the fountain itself, or used a siphon to make water flow.

In Roman cities, water for drinking fountains was distributed from Aqueducts through a systems of lead pipes, upward through a siphon to spout, which pour the water down into a basin. The pressure of the water coming through the pipe from the aqueduct, higher than the fountains, combined with the siphon effects, keep the water running continually.

From the Middle Ages onwards, fountains in villages or towns were usually connected to springs or channels which brought water from aqueduct or rivers. In province, in France, typical fountains consisted of a pipe or aqueduct with a tube running upward into a bulb shaped vessels, like a large vase with a cover on top. The inside of the vase, called the basins, was filled with water on to a level just above the mouth of the canons, or spouts, which slanted downward. The water poured down through the canons, creating a siphon, which drew more water up from the water supply into the basin, so that the fountain runs continually. It was not possible for fountain to recycle the same water then, so fountain needed a continuous supply of water. Residents of the town or city filled vessels or jars of water from the canons of the fountain. Horses and domestic animals could drink the water in the basin below the fountains.

Naomi (1998) opined that the most famous fountains of the Renaissance, at the villa d'Este in Tivoli, were located on a steep slope rear a river; the builders ran a channels from the rivers to a large fountain at the top of the gardens, which then fed other fountains and basins on the level below.

Baroque decorative fountain, such as fountains in the Gardens of Versailles, used water pressure from gravity and specially designed nozzles, or Tuyas, to shoot water upwards and to form it into different shapes, such as Fans, Bouquets and Umbrellas. The Versailles fountains required the building of enormous machines with 14 water wheels and 220 pumps which lifted the water 162 metres from the seine to a reservoir above the gardens. Even so, the fountain used so much water that 


\section{Production of a Model Water Fountain Using Ceramics for Interior Decoration in Anambra State}

they could not all be used at the same time. Fountainers watched the progress of the king when in toured the gardens and turned on each fountains just before he arrived.

In modern fountains, the traditional gravitational pressure from unseen reservoir at a higher level is not always practical. In many circumstances, fountains obtained their water from a closed, recirculation system that must still be filled at the start from the local water supply system and below.

According to Blair (2001) reviewed that fountain are of different types depending on the authors. From Google search (www.beyondtheveranda.com>typ...), it is stated that there are five types of garden fountains;

Tiered Fountains: they are very popular and have been sued in gardens for years. These can be seen in Mediterranean countries like Spain and Italy. They are installed in courtyards and plazas. They look great in traditional or classical setting.

The second one is Disappearing Fountain: this is more economical and safe for the following reasons; the reservoir is underground and there is no open water pond or basin, there is no drowning risk. Also, since the water body is underground, the water does not evaporated therefore less water is used. It requires very little maintenance because dirt, debris and leaves cannot enter the reservoir and the sum cannot cause alge growth. It can be installed anywhere because it takes up a very little space.

The third type is Japanese Fountain: this is located at the entrance of a Japanese temple or home because it symbolizes spiritual and physical cleansing. It has a very simple designs, with the focus on the water rather than the basin.

The fourth type is Wall Fountain: this looks perfect in a courtyard or a small patio as it gives the sense of relaxation. This fountain does not take up too much space and can be customized to fit on a particular wall.

It requires a spout, water basin, internal tubing, and a pump. It can be either free standing or mounted. The styles include traditional, modern, antique or Asian.

The fifth type is Self-contained Fountains: these are affordable and can be installed quite easily. They contain all the working parts including the plumbing and pump required to function. It can also refer to fountains that have their own water reservoir and therefore don't need to be placed in a pond or pool.

Paun (2010) in his study water fountain (garden. Love to know.com>wiki>wa....) says that Water Fountains are of three types; they are Trough fountains, Animated fountains and Splash fountains.

Trough fountains are found in traditional culture around the world. It is easy to create this kind of fountain in your garden. A hidden hose fed into the spout of your choice will allow water to trickle gently into a trough below, so that you can enjoy the soothing sound of moving water in your garden.

Animated water fountains push jets of water into the air, which then fall back to a basin below. On a large scale, these fountains may be enhanced by coloured lights and music to delight the public.

Splash fountains: sometime called bathing fountains or spray grounds have begun to be popular in public areas. Children and many adults have always cooled off in public water fountains and now fountains are designed for this purpose.

Paun further discussed the functions of the reservoir, pump and fountain head as three primary components of water fountain. Fountain Reservoir is a basin that stores water. The water returns to reservoir after completing a cycle. Basins are generally made of flexible rubber or hand plastic which makes them water proof. The reservoir is either open and resting on a hard surface or hidden in the ground. For fountains used to aerate a pond, the main body of water functions as a reservoir.

Fountain pump is the most important component because it controls the flow as it cycles from the reservoir to the fountain head. Submerged pimps reside in the reservoir, while dry mount pumps sit outside the basin. All types of pumps feature an election powered impeller, which is a rotating component that draw water in at a rapid speed. The pump ejects water by centrifugal force into a pipe or hose, which directs water to the fountain head. Fountain head is where the water effects begin. Consumers can choose fountain heads that provide a simple, cascading water fall. They should look for fountain heads with nozzles that spray water droplets in a pattern for elaborate displays.

In addition, there are several other components added to the three main parts of a garden fountain. Some are optional such as junction box.

Water treatment system ensures the quality of the water oxidizing treatment reduces bacteria and algae.

Junction box; this houses the power supply for the pump water proof.

Drain; suction drain circulates the water overflow. Drain also removes excess water.

To enhance the look of the feature at night, owners can install fountain lights submerged lighting creates a shimmering effect on water while spotlights accent. 


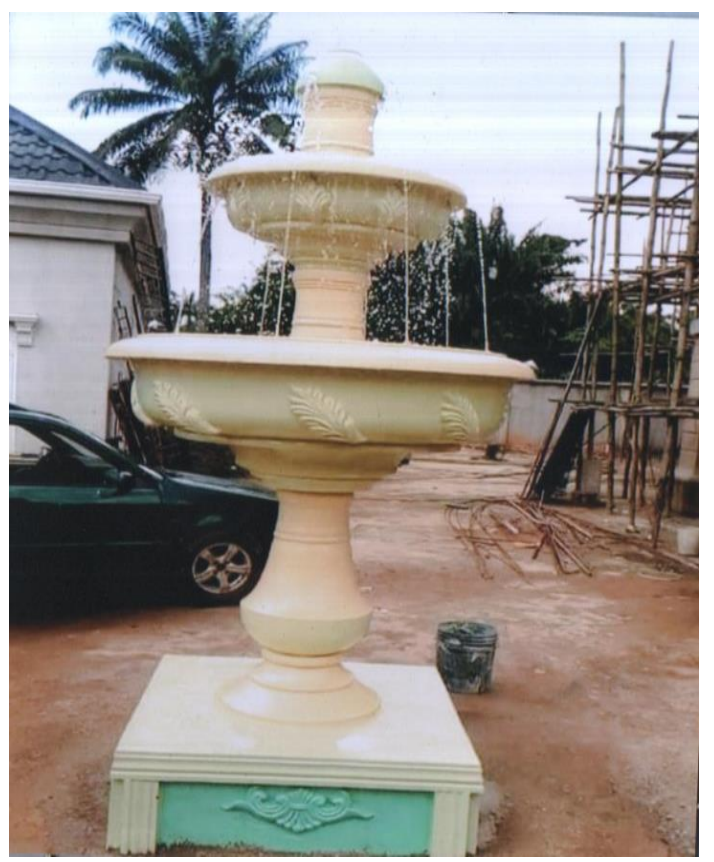

Plate 1

Chika Onyema (2018)

Title: Water Fountain

Media: Concrete

\section{Summary of Literature Review}

Having seen some of the fountains in Anambra State and its environment, it has been found out that most of them are made with metal and cement.

Also, water fountain for interior decoration is not common in Anambra State rather they were mainly outdoors.

From the available literature it was observed that there is lack of proper knowledge of roles and significance of fountain. These gaps are holes to be filled by the project.

\section{RESEARCH METHODOLOGY \\ Research Design}

Since the research is studio based, the practical experimentation method was adopted. As the researchers work on production of model water fountain for interior decoration, the main media are ceramic materials. The methods of execution are throwing, coiling and scooping.

\section{Sources of Data}

The sources of data are primary and secondary. Primary sources are in the form of oral interviews, while the secondary sources are published and unpublished literature which include textbooks, journals and related works.

\section{Method of Data Analysis and Evaluation}

The qualitative method was adopted for this study. The successes or failure of this research would be assessed analogically based on the performances of existing related works.

\section{Area of Study}

The study area is Anambra State. Anambra State is in South-Eastern Nigeria. Its name is derived from Oma Mbala River. The capital of the State is Awka. Onitsha and Nnewi are the biggest commercial and industrial cities, respectively. The indigenous ethnic group in Anambra State are the Igbo ( $98 \%$ of population) and a small population of Igala ( $2 \%$ of the population) who live in the North Western part of the state. Anambra is the eight most populated states in the Federal Republic of Nigeria and the second most densely populated in Nigeria after Lagos State. The stretch of more than $45 \mathrm{~km}$ between Oba and Amorka contains a cluster of numerous thickly populated villages and small towns giving the area an estimated density of 1,500 - 2,000 persons living within every square kilometer of the area. Anambra is rich in natural gas, crude oil, bauxite, ceramic and has an almost 100 percent arable soil. Having gone round the state, it was noticed that most water fountain were outdoors thereby the 


\section{Production of a Model Water Fountain Using Ceramics for Interior Decoration in Anambra State}

researchers intend to experiment on the indoor fountain so that people may comfortably relax in their house watching the movement of water and its sound.

\section{Material and Tools Used for the Research}

The chief material which is used in production of this practical project is stone ware clay. This was sourced from Akure, Ondo State.

It contain fillers that reduce the rate of shrinkage and warping in drying and firing stages. Such fillers are flint, silica, sand, sawdust, mullet, kaolin, alumina and grogs.

It is defined as a vitreous or semi-vitreous ceramic made primarily from stoneware clay or non refractory fire clay. The temperature of stoneware is relatively high to about $1200^{\circ} \mathrm{c}-1300^{\circ} \mathrm{c}$.

Tools and equipment used by the researchers were throwing wheel, cutting wire, rolling pin, plastic bucket, bowel, knife, saw blade, syringe, gas kiln, sponge, wooden board, rubber kidney.

\section{Production Processes}

The processes of producing "A model water fountain using ceramics for interior decoration" is hereby discussed in stages.

Stage 1:

\section{Preparation of Clay}

After sourcing the materials from Akure, Ondo State, the researchers started the preparation by first of all soaking the clay (stoneware body) in a plastic container to stay about four days. Then it was sieved with 90 grade of mesh and allowed to settle before decantation of the excess water. The researchers later poured the watery clay on a cemented floor where it was left to dry to a stiff stage before kneading. During kneading all those fillers (flint, silica, sand, sawdust, kaolin, alumina and grogs) were added and this process lasted for hours to ensure proper and thorough mixing.

This was later wrapped in balls, with cellophane bags and put in a plastic bucket for ageing to stay atleast one week. When the researchers completed the preparation process, the production takes off.

\section{Stage 2:}

\section{Conception Stage}

Inspiration for creating a model water fountain was born out of researchers desire to contribute to the beautification of environment.

However, there will be continuous trial and error until the required success is achieved. Ideas come from observing the several water fountains around.

\section{Stage 3}

\section{Sketches of the Parts and Assembled Wares}

This will be done following the ideas and concepts developed; and it will guide the researcher on the production of the practical project.

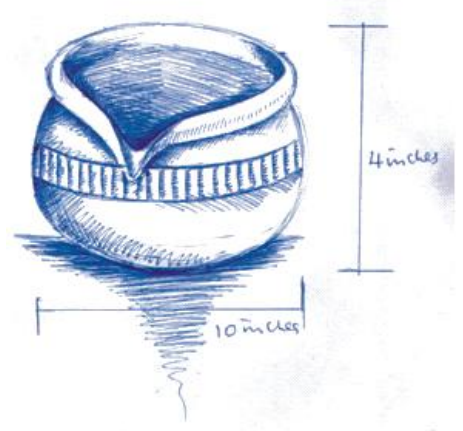

Fig. 1: Small Bowl with Spout 


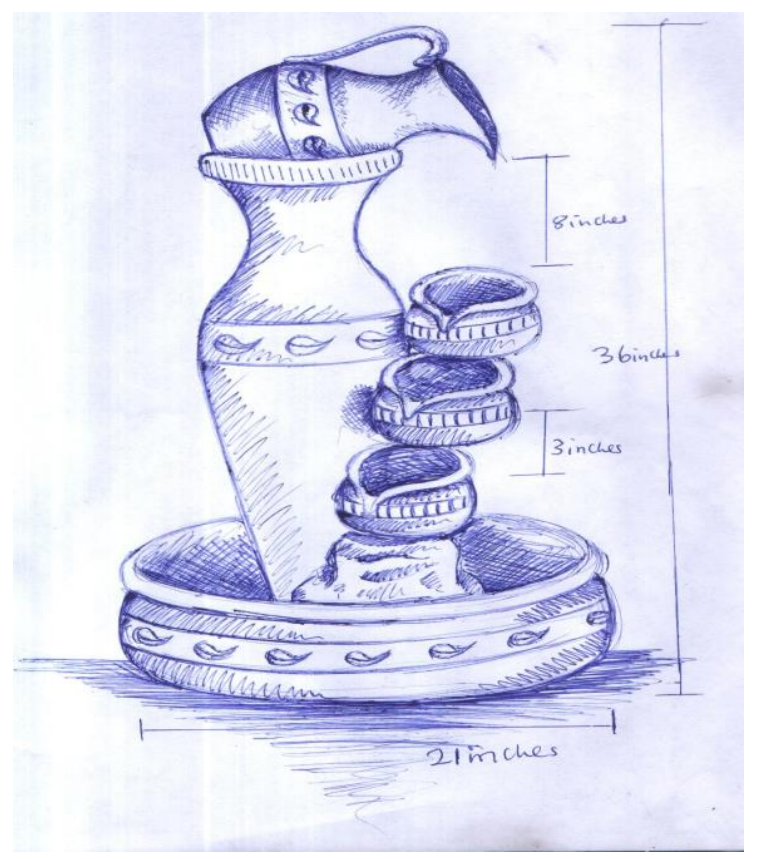

Fig. 2: Assembled Ware

\section{Stage 4}

Kneading of the Clay

The researchers kneaded the clay on a wooden board using hands. Later on, made the clay in balls for easy throwing of the wares.

\section{Stage 5}

Throwing of the small bowls and jugs, coiling of vase and big bowl and modeling of stone that serve as the base.

The thrown wares were achieved by first of all centering of the clay balls, then opened with thumbs, followed by building up cylinders and lastly formed to desired shape. The stone (base) was formed from kneaded clay and later allowed to be leather hard before cutting. Lastly, the big bowl and vase were built using clay coils.

\section{Stage 6}

Trimming of the thrown wares and scooping of the base (stone).

The wares were trimmed with turning tools, and cleaned with wet foam while the stone was cut, scooped and joined back.

\section{Stage 7}

\section{Decoration of the Ware in Parts}

The ware was decorated using embossed and incision methods.

Stage 8

Joining of the work (Assembling):

The whole wares were joined by first of all scratching the areas where joining will take place, then applying clay slip while the two surfaces were joined and sealed with tiny coils using knife and saw blade.

\section{Stage 9 \\ Drying:}

The researchers exposed the ware to dry naturally. Despite the weather, the ware dried very fast due to the refractoriness of the clay body. 


\section{Production of a Model Water Fountain Using Ceramics for Interior Decoration in Anambra State}

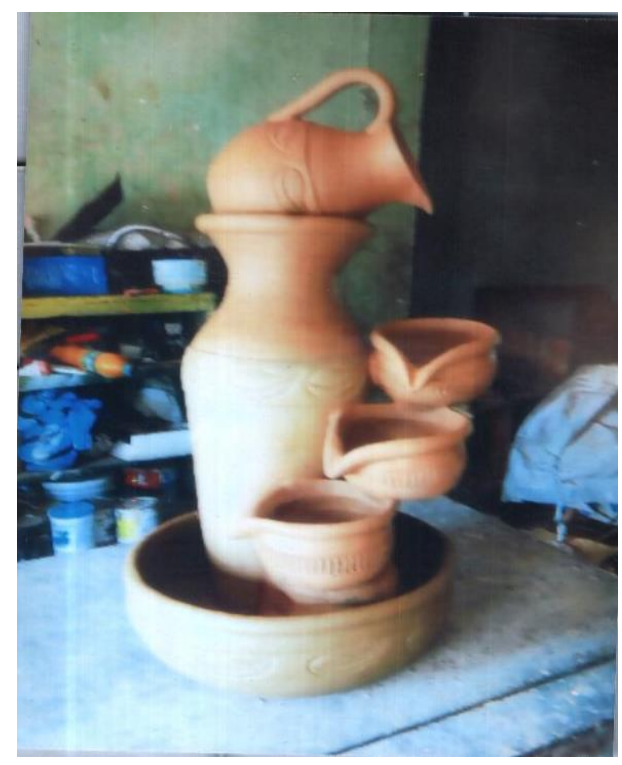

\section{Plate 2:}

Dried Ware

\section{Stage 11}

Firing (Bisque and Glost Firing)

The ware undergone first firing (Bisquit) at temperature of $1100^{\circ} \mathrm{c}$, then glazed using pouring method. The researchers allowed the glazed ware to dry with the aid of dryer after which loaded and glost fired at the temperature of $1250^{\circ} \mathrm{C}$.

Finally, the ware was allowed to cool at about $50^{\circ} \mathrm{c}$ before opening of the kiln for off loading.

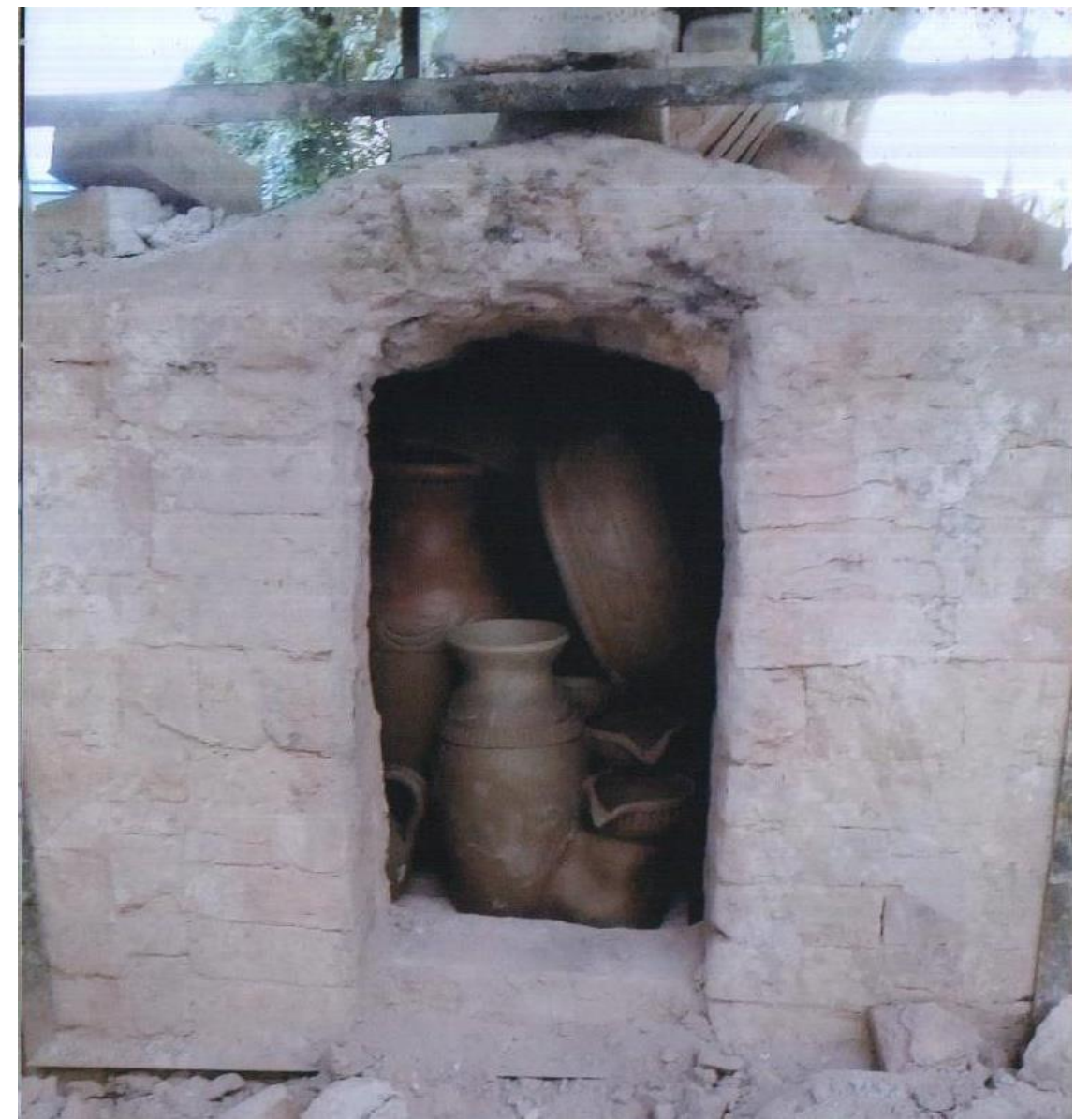

Plate 3:

Bisque Firing 


\section{Production of a Model Water Fountain Using Ceramics for Interior Decoration in Anambra State}

\section{Project Analysis}

Ceramic ware construction is designed to serve as a model water fountain for interior decoration. This is a free standing piece which is aimed at enlightening the society that fountain can be achieved using ceramics. Ceramics is known for its durability and stain free nature, which makes it easy to maintain.

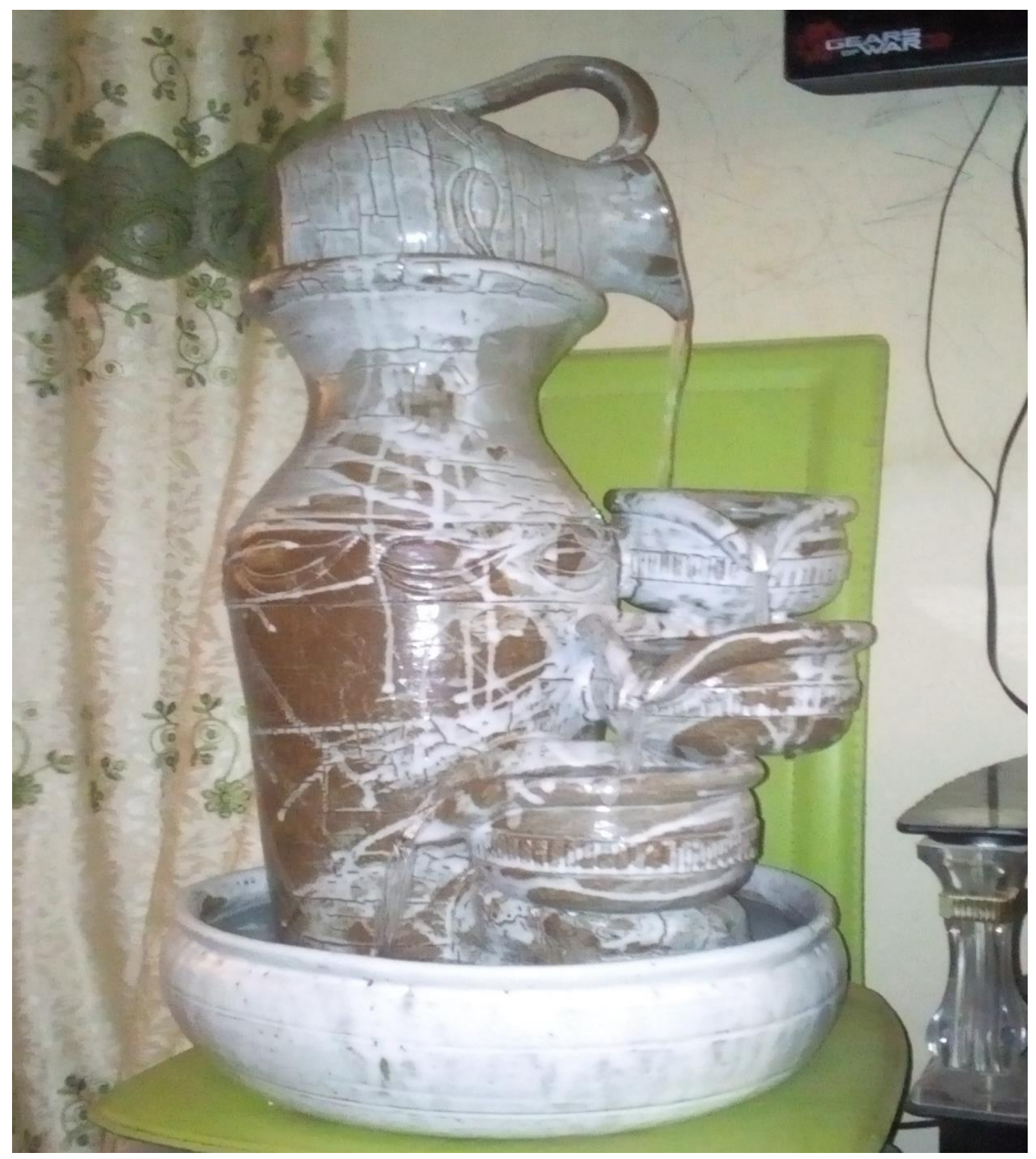

Plate 4:

Finished Ware

Ceramics is nature friendly, always cool when especially the glazed ware felt. Also, almost all the materials used in production of this work is from the earth. The work measures 36 inches $\times 21$ inches. The work comprises of a bigger bowl that serves as reservoir, a pot, a jug that pours water to three smaller bowls with spouts and a stone that serves as the base.

The model fountain works this way; the reservoir that is filled with water through piping supply water to the pot when it is switched on, from the pot to the jug, then the jug pours water to the topmost small bowl to the middle, and to the lowest, on top of the stone that serves as the base.

This continues recycling until it is switched off and that is the interesting part of it. Since water fountains that are outdoors can entertain and interest people, the researcher thought it wise that it is a good thing to bring it home (Sitting room) for people to relax with and ease off some tensions and worries.

The position of the water fountain in the sitting room made this project a standard and a well defined work that can attract any visitor that comes in. 


\section{Production of a Model Water Fountain Using Ceramics for Interior Decoration in Anambra State}

Along with serving practical purposes, the fountain also provides aesthetic benefits. All fountains, even those designed for specific use, are generally aesthetically pleasing. Aesthetics therefore is built into almost all fountain. The model ceramic fountain was designed to attractively display water in dripping, flowing, splashing form. It therefore represents a very conspicuous use of water, as such it attracts notice and comment in ways and manner of the continuous flow of water.

The objects used in the construction of the ware are what we see in our day to day lives, so it is not scary, it is what one can feel or touch. The bigger bowl and the pot were achieved using the coiling method, the jug and smaller bowls were also achieved using throwing method and the stone was achieved with the scoop method. All these were possible with stoneware body. The arrangement is quite interesting. The researchers tried to fire bisque first after drying and lastly glost fired it.

This is to enhance the look and make it more beautiful and shiny. For functional purpose, this work will be placed at a strategic point in the sitting room, so that whoever comes in will be attracted by it. It will help to beautify and give a new look to the sitting room.

\section{Findings}

One of the findings made in the course of this study is that in Anambra State water fountain in general is scarcely found. Also, that the ones seen are mainly sculptures not ceramics and outdoor water fountain.

Moreover, the available water fountains are poorly maintained as regards to changing the reservoir water, servicing the pump among others. Another finding is that the water inside is cooler than that of sculpture because of the ceramic materials used in production.

Finally, water fountain as an art piece draws attention.

\section{SUMMARY AND CONCLUSION \\ Summary}

Water is very important for all living being. Naturally, water cycle keeps providing us with fresh water continuously. This is reversible cycles, which means every stage in the cycle keeps repeating itself. This is also applicable in the water fountain.

Some of the water fountains and water fall designs we have seen in some major recreational facilities owned by States, schools and private entities are obsolete. Fountain and waterfall designs in Nigeria have been crying for a major transformation and the researchers are here to correct the flaws by maintaining its efficiency and cleanliness.

\section{CONCLUSION}

Water fountains are common architectural feature in Nigeria found in public places like plazas, malls, in front of government and office buildings, industrial building and residential houses for exterior decoration. This study specifically treated the water fountain for interior decoration. The design of water fountain appear in all shapes and sizes, their waters variously displayed, from a slight trickle to a cascading flow to a gushing geyser. Most water fountain especially outdoor serve the function of supplying drinking water, cooling off for those that have worked all day. With this, it is obvious that fountain is not only being designed for environmental beautification rather for relaxation.

However, by providing people the opportunity to experience the fascination and pleasure of water, water fountains encourage them to value water for its beauty and the physical and psychological satisfaction it offers. The materials used in production of the fountain are mixture of different clays that form stoneware body. Through critical study of previous fountains the inspiration of this work came up. The fact that we rely on water for our day to day activities explains more our attraction to fountain in our environment.

The research speaks to consciences in different ways. More so, it creates awareness of the importance of fountains as decorative pieces in an environment. It also informs the society at large about the possibility of using ceramics as an alterative to the sculpture and metals.

\section{REFERENCES}

1) Allain and Christiany (1994). "I'art des Jardins eu Europe and "Fountains as Propaganda", in the Collection Fountains Splash and Spectacle, Paris: Marilyn Summer:.

2) American Heritage Dictionary of English Language, Fifth Edition (2016) New York: U.S.A. Harcourt Publishing Company.

3) American Heritage Student Science Dictionary, Second Edition (2014). New York: Houghton Mifflin Harcourt Publishing Company.

4) Attlee, Helena (2006). Italian Gardens - A Cultural History. Francis Lincoln Limited. 


\section{Production of a Model Water Fountain Using Ceramics for Interior Decoration in Anambra State}

5) Blair, Jennifer (2001). Landscaping Network: Outdoor Wall Fountain Designs. Mary Land, New York: John Hopkins University in Baltimore.

6) Boehim, Richard D.; Armstrong, David G and Hunkins, Francis P. (2003). Geography - The World and Its People. New York: McGraw Hill Companies.

7) Charlotte (1990). American Women Sculptors: A History of Women working in three dimensions, Chicago in the Bethesda fountain in New York City: Pitman Publishers.

8) Collins English Dictionary - Complete and Unabridged, $12^{\text {th }}$ Edition (2014). London: Harper Collins Publishers.

9) Cornelli and Symmes (1989). Outdoor decorations, London: Pitman.

10) Dictionary of Unfamiliar Words by Diagram Group Copyright (2008).

11) Fellmann, Jerome D. (2005). Human Geography Landscapes of Human Activities. New York: The McGraw-Hill Companies.

12) Hammer, E. (2005). Adorno and the political, New York: Routeledge.

13) Hammer, E. (2015). Adorno's modernism: Art, Experience, and Catastrophe, Cambridge: Cambridge University Press.

14) Hansen, M.B. (2012). Cinema and Experience: Siegfried Kracauer, Walter Benjamin, and Theodore W. Adorno, Berkeley: University of California Press.

15) Hellings, J. (2014).Adorno and Art: Aesthetic theory Contra critical Theory, Houndmills, Basingstoke, Hampshire: Palgrave Macmillan.

16) Herodotus, A.I., (1992). The Histories of Fountain, Ontaro: Sithen.

17) Huhn, Tom and lambert Zuider Vaat, (1991). Semblance of Subjectivity: Essays in Adorno's Aesthetic Theory. Cambridge MA: MIT Press.

18) Huhn, T.(2004). The Cambridge Companion to Adorno, Cambridge: Cambridge University Press.

19) Jarvis, S. (1998). Adorno: A Critical Introduction, New York: Routledge.

20) Morgan, A. (2007). Adorno's Concept of life, New York: Continuum.

21) Muobike Chibuzo (2018). Production of Fountain for Decorative and Dramatic Effect on a Built Environment: A project booklet submitted to the Department of Fine and Applied Arts, faculty of Environmental Science Unpublished.

22) Naomi, Miller (1998). Fountains as Metaphor, in Fountains - Splash and Spectacle. London: Maridyn Symmes.

23) Nicholson, Shierry Weber (1997). Exact Imagination, Late work: On Adorno's Aesthetics. Cambridge: MA: MIT Press.

24) Osayande, Owen (2016). The Design and Construction of an Outdoor Water Fountain: A project booklet submitted to the Department of Industrial Design, School of Environmental Technology (FUTA) Unpublished.

25) Oxford Dictionary of English Language (2017). London: Oxford University Press.

26) Paddison, M (1993). Adorno's Aesthetics Theory of Music, New York: Cambridge University Press.

27) Wright Richard T. and Dorothy Boarse (2012). Environmental Science - Towards a Sustainable Future, Eleventh Edition. New Delhi Published by Pearson Education, Inc.

28) Zudervaart, Lambert (1991) Adorno's Aesthetic Theory: The Redemption of Illusion. Cambridge: MA: MIT Press.

\section{Internet search}

1) www.thewaterpage.com?water....fo). Retrieved 25 May, 2017)

2) https://en.m.wikipedia.org>wiki> Retrieved 17 August, 2017.

3) www.beyondtheveranda.com?typ... Retrieved 12th Feb. 2018

4) garden.love to Know.com>wiki>wa... accessed Dec., 2016. http://.en.wikipedia.org/wiki/file.internationalfountain. Retrieved 12th Feb. 2018.

5) Wikipedia the free encyclopedia https://www.iep.htm.edu - aesthetic (Retrieved 25 May, 2017). 